\section{EPISTEMOLOGICAL STUDIES IN PHILOSOPHY, SOCIAL AND POLITICAL SCIENCES \\ ISSN 2618-1274 (Print), ISSN 2618-1282 (Online) \\ Journal home page: https://visnukpfs.dp.ua/index.php/PFS/index}

\section{Віктор Миколайович Щербина}

Доктор соціологічних наук, професор

Професор кафедри соціології

та соціальної роботи

Класичний приватний університет

Вул. Жуковського 70-б, Запоріжжя, 69002,

Україна

\section{Юрій Вікторович Романенко}

Доктор соціологічних наук, професор

Професор кафедри міжнародних

медіакомунікацій та комунікативних технологій

Інститут міжнародних відносин КНУ

вул. Володимирська 60, Київ, 01033, Україна

E-mail: romanenko.jura@gmail.com, ORC
Viktor Mykolayovych Shcherbyna

СОЦІАЬНІ НАУКИ
Professor of the Department of Sociology

and Social Work

Classical Private University

70B, Zhukovsky St., 69000, Zaporizhzhya, Ukraine УДК 316

\title{
ЕВРИСТИЧНИЙ ПОТЕНЦАЛ АКТОР-МЕРЕЖЕВОГО ПІДХОДУ В СУЧАСНОМУ СОЦІОЛОГІЧНОМУ ТЕОРЕТИЗУВАННІ
}

Received 30 July 2019; revised 27 August 2019; accepted 20 September 2019 DOI: $10.15421 / 341927$

\section{Анотація}

Викладено основні положення актор-мережевого теоретичного підходу Бруно Латура. Проаналізовано з точки зору проблем дослідження соціальних мереж евристичний потенціал концепиіі гетерогенної мережі, яка утворюється в процесі взаємодї різнорідних елементів - як соціальних, так i технологічних. Виявлено, що «матеріальний поворот» та актор-мережевий підхід є плідним щзодо дослідження специфіки соиіальної взаємодії на рівні малих соиіальних мереж; актор-мережевий підхід не є придатним для дослідження мікросочіальних прочесів, оскільки не відповідає їх історичній природі.

Ключові слова: соціальні мережі, Бруно Латур, актор-мережевий підхід, матеріальний поворот об'єкт-центричність, соціальна теорія.

\section{The heuristic potential of the actor-networking approach in modern sociological theorizing Abstract}

The article outlines the main points of tBruno Latour's actor-network theoretical approach. The innovation proposed by Bruno Latour, the basic principle of his theorizing paradigm, is the concept of a heterogeneous network. According to his vision, such a network is formed in the process of interaction of heterogeneous elements - both social and technological. It is essential that these elements should be described as equivalent, equally important to the existence of the interaction network. The network is thus made up of diverse actors - people and objects, technical standards, technical devices, software. Hence, social order arises as a result of the activity of all its elements and is broken by the exclusion of any element from the process of such joint interaction. Therefore, social order can be disrupted as a result of changes in social behavior and as a result of changes in technical standards or technological disaster. The basic principle of the theory is that people do not have a special position in the network, they are viewed without any difference from other participants in the interaction in the network - first of all, because without other actors, people can not exist. Humans and objects are seen as nodes of a hybrid network, which itself looks like an aggregate of agents who interact to solve common problems by solving common problems. Thus, the common purpose of the activity should be seen as being formed not only by the person but also by all other agents of the network. The heuristic potential of the concept of heterogeneous network, which is formed in the process of interaction of heterogeneous elements - both social and technological, is analyzed in terms of problems of social network research. It is concluded that the "material turn" and the actor-network approach is fruitful for the study of the specifics of social 
interaction at the level of small social networks. The actor-network approach is not suitable for the study of microsocial processes because it does not correspond to their historical nature. The proposed approach outlines the prospect of updating the body of theoretical knowledge about society by introducing things and intellectual products as independent agents of social influence in the subject sphere of social reflection.

Keywords: social networks, Bruno Latour, actor-network approach, an object-centered, social theory.

\section{Эвристический потенциал актор-сетевого подхода в современном социологическом теоретизировании Аннотация}

Изложены основные положения актор-сетевого теоретического подхода Бруно Латура. Проанализированы с точки зрения проблем исследования сочиальных сетей эвристический потенциал концепции гетерогенной сети, которая образуется в процессе взаимодействия разнородных элементов - как сочиальных, так и технологических. Выявлено, что «материальный поворот» и актер-сетевой подход плодотворным по исследованию специфики социального взаимодействия на уровне мальх социальных сетей; актер сетевой подход не пригоден для исследования микросоциальных процессов, поскольку не соответствует их исторической природе.

Ключевые слова: социальные сети, Латур, актор-сетевой подход, материальный поворот, объект-центричность, социальная теория.

\section{Постановка проблеми.}

Глобалізація, інформатизація, виникнення новітніх інформаційних середовищ призвели до появи нових компонентів суспільного життя. На переломі віків у суспільствознавстві набуло широкого розповсюдження бачення суспільства як динамічної мережі, в якій відбувається соціальна взаємодія, яку можна описувати як множину потоків. Таке бачення актуалізувало необхідність створення відповідних новій базовій метафорі концептуальних уявлень, на основі яких стало б можливим створити теорії, які будуть мати евристичний потенціал відповідно до потреб соціального пізнання нової доби. Однією з таких нових платформ соціального пізнання виступила парадигма актор-мережевої взаємодії, що передбачає мережеву логіку описування соціальних процесів. Один з піонерів такого підходу, іспанський соціолог М.Кастельс, вважає, що мережана логіка як така суттєво впливає на процеси суспільного життя, визначаючи обличчя сучасних соціальних рухів, державних та недержавних утворень. Поняття «соціальна мережа» набуває усе більшого розповсюдження, його використовують як у науковому пізнані, так і у повсякденному житті. Суспільство починає розумітися як таке, що має мережану основу, будується на основі процедур узагальнення процесів, що відбуваються у соціальних мережах. Поняття соціальної мережі ото- тожнюють з особливим їх різновидом, який формується на основі кіберкоммунікативного спілкування - тобто з такими мережами як «Фейсбук», професійними та розважальними ресурсами міжособистого спілкування. Ці мережі часто протиставляються традиційним соціальним інститутам, інтерпретуються як носії «дійсної правди реального життя», стають середовищами формування соціального запиту до влади, засобом не тільки комунікації, а й самоорганізації тих людей, які виключені з процесу впливу на державні інституції. У науковому вжитку поняття соціальної мережі досліджується останнім часом доволі предметно, однак темпи суспільних змін в наш час набули настільки карколомного характеру, що соціальне теоретизування не встигає виробляти відповідні їх потребам пізнавальні інструменти і практики. Фокуси досліджень в цій галузі зосереджені в рамках окремих предметних галузей соціології, філософії, культурології тощо, це не сприяє виробленню нового мета теоретичного, синтетичного бачення мережевих взаємодій як певної суспільної універсалії. В цьому сенсі амбітною заявкою стала концептуальна програма переосмислення соціального теоретизування, автором якої $€$ французький філософ, соціальний теоретик Бруно Латур. Він запропонував низку підходів для побудови теорії нового типу та концептуальних засобів для переосмислення «теорії як 
такої» - тобто базових онтологічних установок соціально-філософського і соціологічного мислення. Зважаючи на наявну необхідність вироблення нових теоретичних підходів, існує необхідність концептуального засвоєння його позиції в процесі наукового пізнання сучасних суспільних процесів. Це і визначило актуальність статті, що пропонується до розгляду.

Стан останніх досліджень проблеми.

Теорія соціальних мереж найбільшою мірою розроблена у французькій соціології. У наукових роботах багатьох авторів базовою аналітичною одиницею соціального виступає «соціальна мережа», або «актор-мережа». Цю одиницю розуміють як таку, що включає в себе не тільки індивідів, але й різноманітні громадські та природні компоненти, які підлягають дії та діють самі, впливаючи на соціальну систему в цілому. Однак на теоретичному рівні мережана термінологія не достатньо розроблена і непослідовна, вона включає багато понятійних запозичень 3 різних галузей знання, припускає часом відверто метафоричне уявлення про предмет, який розглядається. Це значно ускладнює процес отримання практично значущого знання, перетворює науковий дискурс щодо соціальних мереж на простір довільного описування. Загалом в сучасному суспільствознавстві склалася низка теоретичних підходів до розуміння соціальної мережі. Першим таким підходом передбачається розуміння соціальної мережі як домінуючої відносно інших соціальних процесів. Представники іншого підходу (т.зв. батської школи) розвивають теорію соціальної мережі як акторно-мережеву теорію. Прибічники підходу, одним 3 фундаторів якої є Бруно Латур, також розвивають актор-мережеву теорію, однак вкладають в свою діяльність різні значення. Бруно Латур та Мішель Кантоном значної уваги надають формуванню загальнотеоретичних та метрологічних засад цієї теорії. Окремо можна виділити також роботи ланкастерських соціологів - Джона Ло, Анн-Марі Мол, Мадлен Акрич, Нильса Альбертсен, Викторії Синглтон, Джона Уррі, які більшою мірою орієнтовані на науково-технічні аспекти дослідження мережевих взаємодій.
Творчість Бруно Латура не є предметом значного інтересу з боку вітчизняних дослідників. Він є одним з ідеологів акторно-мережевої теоретичної орієнтації (Actor-Network Theory, ANT), прихильники якої бачать своє завдання у фундаментальній ревізії оптики і словника дисципліни. Заявлені теоретиками ANT ціннісні установки на пошук шляхів оновлення авторитетності наукового знання формально зближуються зі сцієнтистськими позиціями. Така позиція виглядає неприйнятною та незрозумілою для тих дослідників, що стоять на позиціях наукового реалізму, а з цих позицій вони не можуть дати їм адекватної оцінки. Це спричиняє радикально-критичне відношення до ідеї і методів Латура. Можна сказати, що це фіксує непрозорість сучасних наукових парадигм соціального пізнання до новизни і радикальності - не зважаючи на всю декларовану ними потребу в парадигмальному оновленні. Дискусії між представниками критичної соціології і дослідниками, що стоять на позиціях нового «матеріалізму»/«реалізму» не дозволяють також скористатися структуралістськими і поструктуралістськими підходами, що їх розвивають сучасні українські соціологи (Н. Костенко, В. Бурлачук, М. Соболевська, В. Щербина).

За таких умов інтерпретації латурівської концепції формуються з різних точок зору з погляду їі внеску у розвиток міждисциплінарних досліджень науки і технології (Science and Technology Studies, STS) - В. Сінглтон, А. Молл, М. Акріч, Н. Альбертсен, Н. Іванова, Ю. Моркіна, І. Полонська; з погляду на матеріальний поворот в соціологіï (Turn to the material) - Д. Пелс, К. Хезерінгтон, Ф. Вандерберге, Р. Харре, К. Кнорр-Цетіна, Д. Кул, С. Фрост, Д. ЛаКапра, Я. Годдер, М. Фрейзер, С. Кембер, В. Вахштайн, А. Кузнєцов; прагматичний поворот (The Pragmatic Turn) - O. Xapхордін, В. Волков; поворот до «не-людського» (The Nonhuman Turn) - Е. Доманская, Ф. Вандерберберге; поворот до складності (Тhe Complexity Turn) - Б. Кастеллані; семіотичний поворот - I. Напреенко, Р. Хорстакер; онтологічний поворот - А. Ескобар, Н. Костенко, С. Астахов, О. Столярова, та інші повороти в 
теорії кінця XX - початку XXI століття. Узагальнююче дослідження евристичного потенціалу концепції Бруно Латура щодо власне соціологічного теоретизування в українській соціологічній спільноті здійснила Я.Кононова [Кононова 2013].

За умов ситуації, що склалася, потенціал пропонованої Бруно Латуром акторно-мережевої теоретичної орієнтації не засвоєний науковою спільнотою достатньою мірою та виглядає таким, що не витримує критики в рамках предметів різних суспільствознавчих наук. Однак власне амбітною заявкою Бруно Латура $\epsilon$ намагання побудови теорії нового типу, переосмислення «теорії як такої» - тобто базових онтологічних установок того, як наука розуміє та описує суспільні процеси.

Метою статті аналіз евристичного потенціалу введення положень концепції актор-мережевої теоретичної орієнтації Бруно Латура та введення іiі положень у науковий обіг вітчизняного суспільствознавства.

\section{Виклад основного матеріалу.}

Взаємозв'язок між технологічним розвитком і змінами в соціальній структурі $є$ здавна предметом розгляду філософів, економістів, соціологів. В рамках розвитку цієї парадигми сформувалися низка теорій, відповідно до яких промислова революція породила капіталізм, революція в інформаційних технологіях сприяла виникненню сучасного інформаційного (мережного за своєю структурою) суспільства. Відтак в наш час використання комп'ютерних технологій впливає на всю суспільну структуру. Завдяки якісно новим засобам комунікації «домінуючі функції й процеси виявляються організованими за принципом мереж». А все суспільство в цілому стає «мережним» [Кастельс 1999]/

Найважливіша галузь застосування мережної теорії - зміни, що відбуваються в соціальній стратифікації. У суспільстві, побудованому на основі комунікацій, що продукуються в рамках мережних структур основним ресурсом виробництва стають знання й інформація, а пануючою соціальною групою - ті, хто має знання. Природньо, що у процесі становлення цього нового соціального угрупування - «класу інтелектуалів» або «нетократії» [Бард $\&$ Зодерквист 2005] важлива роль приділяється технологіям комунікації. Говорячи про засоби комунікації, як правило, мають на увазі комп'ютерні мережі, зокрема, Інтернет. У цьому проявляється технологічний детермінізм, від якого необхідно перейти до більше пильного розгляду взаємодії людини й комп'ютера, і ширше - зв'язку між суспільним порядком і глобальними кіберкомунікаційними мережами.

Теоретичний опис структурних трансформацій соціальної реальності, що формується під впливом розвитку мереж, пов'язаний з новими підходами до вивчення взаємодій між соціальними акторами. Такий опис не позбавлений крайнощів та перебільшень, однак це $є$ природнім коли мова йде про історично новий процес соціотворення. У сукупності ці взаємодії утворюють соціальний капітал, що $\epsilon$ необхідною умовою мобілізації колективних ресурсів у сучасних суспільствах. Зростання ролі мережних комунікацій, у тому числі неінституціональних обмінів i неформальних солідарностей, актуалізує мережі як чинник творення соціальної реальності.

Для соціальних теоретиків завжди було важливим зрозуміти те, як індивіди зв'язані один з одним, і як ці зв'язки обумовлюють порядок і зміст соціального життя на мікрорівні. В 1970-ті pp. XX ст. актуалізація уваги до мереж зв'язків додала дослідженням соціального життя настільки необхідних їм чутливості і динамізму.

Незважаючи на порівняно недовгу історію вивчення мереж як соціального явища у соціальних науках, саме становлення соціальної теорії пов'язане із проблематизацією структурних зв'язків у класичній соціологічній традиції. В наш час «мережі» і ширше «соціальні мережі», або «мережні структури» розробляються не тільки в рамках соціальних наук, але й у менеджменті стосовно до нових форм організації компаній.

Евристичність мережного підходу пояснюється, насамперед, його сучасною широкою емпіричною застосовністю, що дає вихід на міждисциплінарні теоретичні узагальнення. Завдяки 
мережному підходу відкривається можливість установлення «розмитих» солідарностей, що трансформують соціальні інститути. В економічній соціології й соціальній антропології поняття мережі використовуються як інструмент для вивчення сформованих інституціональних відносин і застосовуються до широкого кола явищ, наприклад до «етнічного» економіці, ситуаціям прийняття на роботу і т.ін.

Загалом у рамках мережного підходу розрізняють два основних типи соціальних мереж - соціоцентричні (sociocentric network) і егоцентричні (egocentric network). У дослідженнях соціоцентричних мереж вивчаються повні структури рольових відносин, тобто розглядаються одночасно зв'язки між всіма членами деякого співтовариства (групи). У дослідженнях егоцентричних мереж обмежуються вивченням соціальних зв'язків окремого індивіда.

Основоположниками актор-мережевої теopiï (Actor-Network Theory, ANT) є французькі соціологи Бруно Латур, Мішель Каллон а також британський соціолог науки Джон Ло. ANT формується на набуває статусу в середовищі дослідників, орієнтованих на міждисциплінарні дослідження «досліджень науки та технологій» (Science and Technology Studies, STS). Цікавим є те, що STS - це ініціатива філософів, істориків, соціологів, тобто суспільствознавців, які намагаються побачити знання як те, що виникає та існує в лабораторіях, у пізнавальних креативних практиках, до яких включено людей, речі, енергії. Методологічні новації ANT полягають у спробі «повороту до матеріальності», відповідно до якого в центрі соціологічного теоретизування має бути проблематика речей, того, що створюється [Латур 2014]. 3 точки зору Бруно Латура такий поворот відриває не тільки нові можливості теоретизування.

Новацією, яку пропонує Бруно Латур, основним принципом його парадигми теоретизування, $є$ концепція гетерогенної мережі. Відповідно до його бачення така мережа утворюється в процесі взаємодії різнорідних елементів - як соціальних, так і технологічних. Суттєво, що ці елементи мають описуватися як рівнозначні, однаково важливі для існування мережі взаємо80 дії. Відтак мережу утворюють різнорідні актори - люди та об'єкти, технічні стандарти, технічні пристрої, програмні продукти. Звідси соціальний порядок виникає як наслідок активності усіх іiї елементів та порушується внаслідок виключення будь-якого елемента 3 процесу такої спільної взаємодії. Тому соціальний порядок може бути порушеним внаслідок як зміни соціальної поведінки, так і внаслідок зміни технічних стандартів або технологічної катастрофи. В цьому відношенні яскравим прикладом системних змін соціального порядку є катастрофа на Чорнобильській $\mathrm{AEC}$, яка призвела до фундаментальних змін в нашому суспільстві. 3 точки зору Латура слід розглядати як існуюче все те, що вступає у мережану взаємодію і впливає на поведінку людей - незалежно від того чи $є$ це людина, пристрій, вірус хвороби, вірус-програма або програма-носій штучного інтелекту. Важливо розуміти, що слід досліджувати мережану взаємодію не у категоріях ієрархічної побудови соціуму, а як динамічну горизонтальну мережу агентів, що формують процеси взаємних відносин, впливаючи одне на одного. Речі, таким чином, е не тільки пасивними агентами взаємодії, вони мають форму власної активності і до них слід відноситися відповідним чином.

Принциповим положенням теорії є те, що люди не мають особливого положення в мережі, їх розглядають без будь-якої відмінності від інших учасників взаємодії у мережі - насамперед тому, що без інших акторів людина не може існувати. Люди і об'єкти розглядаються як вузли гібридної мережі, що сама виглядає як сукупність агентів, котрі взаємодіють у вирішення спільних проблем, вирішуючи спільні завдання. Таким чином спільна мета діяльності має бути побачена як така, що формується не лише людиною, але й усіма іншими агентами мережі.

Основними поняттями запропонованої концепції описання мережевої взаємодії є поняття «переклад», «актант» і «чорна скринька» [Латур 2006]. «Переклад» - це спроба встановити зв'язок між двома нееквівалентними феноменами або термінами, мовна гра, що дозволяє кожному актанту ідентифікувати інших в категоріях власного розуміння. Така операція 
дозволяє будувати мережу, є способом побудови спільного простору з різнорідних елементів. Актант - будь-яка діюча інстанція, «діюча особа» в історії побудови і розвитку мережі. Люди і речі, спілкуючись між собою, утворюють мережі, на основі яких виникає соціальний порядок в цілому. Актантом може бути i людина і артефакт і тварина і навіть мікроб - в тому разі, коли він впливає на процес утворення мережі. Тому для аналізу мережі необхідно «переописати» всі об'єкти, які їі утворюють - надавши їм статус «конституанти дії». Поняття «суб' єкта», «особистості», «агента» не підходять, оскільки вони мають надто близьке відношення до тих теоретичних конструктів, де соціальна мережа описується як утворювана виключно людиною. Латур виходить 3 того, що «діяти - означає опосередкувати дії іншого». «Чорний ящик» - це пристрій, який існує перед нами і ми не знаємо («забули») як він утворився, всі операції з його створення для нас виступають аксіоматично вірними. Він утворюється, коли множина елементів починають працювати як один, дії якого є передбачуваними настільки, що немає потреби знати принцип його утворення.

Звернення до речей в актор-мережевій теорії як способу конституювання спільного світу має також і прагматику, пов'язану з політичним життям. Відповідно до такого розуміння соціальні науки мають стати інструментом активного перетворення і суспільства і людського мислення. Свою позицію, французький дослідник аргументує тим, що наприкінці 19 ст. на тлі багаторічних громадянських конфліктів та революційної боротьби виникла потреба у спрощенні політичних процесів. Ця потреба вплинула на процес формування корпусу наук про суспільство. Замість бачення нестійкої арени політичних взаємодій було запропоновано образ суспільства, що існує в готовому вигляді, яке необхідно лише досліджувати, виробляти знання про його суттєві риси. За такого бачення процес створення спільноти відкритими політичними методами перетворюється на процес вирішення низки завдань соціально-інженерного штибу - управляння соціальними процесами 3 використанням знання про невидимі структури і закономірності. Бруно Латур тут виступає продовжувачем більш радикальної позиції Мішеля Фуко і Жака Рансьера, що в своїх теоріях аналізували співвідношення «політичного» і «поліцейського». Друге розумілося як нормативний фундамент здійснення функцій влади та регулювання засад відносин в суспільстві, а перше - як безперервний процес становлення та затвердження ідей рівності. Методологія дослідження влади, яку розвивав Мішель Фуко, пов'язувала iï з виробництвом знання [Фуко 1998]. Виникнення соціальних наук цей дослідник розглядав як наступний щабель системи покарань - перехід практик володарювання від «покарання тіла» до «покарання душі».

В ідеї суспільства, що є джерелом побудови пізнавальних гіпотез, що пояснює реальність та поведінку людей втручанням зовнішніх сил, які маніпулюють агентами без усвідомлення $з$ боку самих агентів, Латур вбачає інсталювання метафізики, від якої соціологія нібито намагається позбавитися, проголошуючи необхідність виключно наукового дослідження реальності. Соціальний конструктивізм, дюркгеймівську програму «пояснення соціального через соціальне», Латур розглядає як методологічну деформацію, оскільки саме суспільство є тим, що конструюється, облаштовується, монтується на основі взаємодії мереж. Тому суспільство, на його думку, не може розглядатися як джерело причинності у мережаних взаємодіях, звертаючись до побудови суспільства неможливо пояснити те, чому та або інша дія та поведінка є стійкою і внормованою. Інакше кажучи, суспільство саме має бути зрозумілим як конструкт, результат взаємодії у мережах, що складаються 3 речей. Саме речі $є$ базовим рівнем аналізу мереж, оскільки вони « мають специфічну якість неподільності на первинні і вторинні якості. Вони надто реальні, щоби бути уявленнями, і надто спірні, невизначені... мінливі, провокативні, щоби відігравати роль незмінних, застиглих, нудних первинних якостей, якими раз та назавжди оснащений універсам» [Латур 2006]. Так «поворот до матеріального» в актор-мережевій теорії набуває політичного 
виміру.

\section{Висновки.}

1. Актор-мережева теоретична орієнтація, що ії розробляє Бруно Латур, може розглядатися в якості одного з парадигмальних горизонтів сучасного метатеоретичного рівня соціального пізнання. Запропонований підхід окреслює перспективу оновлення корпусу теоретичного знання про суспільство шляхом введення речей та інтелектуальних продуктів як самостійних агентів соціального впливу в предметну сферу соціальної рефлексії.

2. «Поворот до матеріального», об'єкт-центричність соціального, що його пропонує автор підходу, має значний евристичний потенціал в умовах розвитку соціальних середовищ, які включають штучний інтелект в якості дієвого чинника дослідження та організації соціальних процесів. Такий підхід дозволяє розвивати нові епістемологічні засоби, вводити в дискурс аналізу соціальних мереж нові складові соціальної взаємодії, опи- сувати їх якості, фіксувати нові форми мереж відносин між соціальними акторами.

3. На нашу думку, намагання пояснити мікросоціальні процеси (зокрема, політичні) через їх зведення до рівня первинних мереж соціальної взаємодії, не мають достатнього евристичного потенціалу, оскільки тяглість процесів соціальних змін виходить за рамки актуальних процесів суспільного життя. Icторичні перетворення вкорінені не тільки в сучасному, їх логіка визначається також минулим і майбутнім - відтак неможливо оцінити специфіку факторного впливу тієї або іншої «констинтуанти дії», виходячи 3 тут-і-зараз описування іiі характеристик у актуальному процесі мережевої взаємодії.

4. Запропонований підхід є плідним задля розвитку базових метафор, концепцій та теорій щодо процесів формування малих соціальних мереж в умовах сучасності. Практичною сферою застосування отриманого нового знання може стати, наприклад, нетворкінг.

\section{Бібліографічні посилання}

Бард, А., Зодерквист, Я. (2005). Нетократия. Новая правящзая элита и жизнь после капитализма. [Електронний ресурс]. Режим доступу https://klex.ru/3mb

Кастельс, М. (1999) Становление общества сетевых структур. Новая постиндустриальная волна на Западе. Антология. Под ред. В.Л. Иноземцева. С. 494-505.

Кононова, Я.В. (2013) Концепція Бруно Латура у перспективі парадигмальної зміни основ соціологічної теорії. Вісник Національного технічного університету Украӥни «Київський політехнічний інститут». Політологія. Соціологія. Право. № 2. С. 47-52.

Латур, Б. (2006) Когда вещи дают отпор: возможный вклад «исследований науки» в общественные науки. Соичология вещей. Сборник статей. Под ред. Вахштайна. М.: Издательский дом «Территория будущего». С. 342-365.

Латур, Б. (2014). Извините, вы не могли вернуть нам материалим? Логос №4 [100] С. 265-275.

Фуко, М. (1998). Рождение клиники. М.: Смысл. 310 с.

\section{Refereces}

Bard, A., Zoderkvist, Ja. (2005). Netokratija. Novaja pravjashhaja jelita i zhizn' posle kapitalizma [Netocracy. The new ruling elite and life after capitalism]. Retrieved from https://klex.ru/3mb

Kastel's, M. (1999) Stanovlenie obshhestva setevyh struktur [Formation of a society of network structures]. Novaja postindustrial'naja volna na Zapade. Antologija. Pod red. B.L. Inozemceva. S. 494-505.

Kononova, Ja. V. (2013) Koncepcija Bruno Latura u perspektivi paradigmal'noï zmini osnov sociologichnoï teorii [Bruno Latour's concept in the perspective of paradigm shift in the foundations of sociological theory]. Visnik Nacional'nogo tehnichnogo universitetu Ukraïni «Kï̈vs'kij politehnichnij institut». Politologija. Sociologija. Pravo. № 2. S. 47-52.

Latur, B. (2006) Kogda veshhi dajut otpor: vozmozhnyj vklad «issledovanij nauki» v obshhestvennye nauki [When things fight back: the possible contribution of "science research" to social sciences]. Sociologija veshhej. Sbornik statej. Pod red. Vahshtajna. M.: Territorija budushhego. S. 342-365.

Latur, B. (2014). Izvinite, vy ne mogli vernut' nam materialim? [Excuse me, could you return the material to us?]. Logos, 4 [100] S. 265-275.

Fuko, M. (1998). Rozhdenie kliniki [Birth of the clinic]. M.: Smysl. 310 s. 